\title{
CARDIOVASCULAR RISK FACTORS - ASSOCIATION WITH LOWER EXTREMITY VERSUS CORONARY ARTERY DISEASE
}

\author{
CORNEL IOAN BITEA ${ }^{1}$, IOAN MANIŢIU ${ }^{2}$, GEORGIANA BĂLŢAT ${ }^{3}$, OANA STOIA ${ }^{4}$

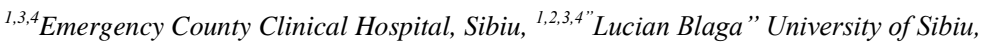 \\ ${ }^{1,3}$ Invasive and non-invasive research centre in the field of cardiac and vascular pathology in adults - CVASIC, Sibiu
}

\begin{abstract}
Keywords: cardiovascular risk factors, C-reactive protein, chronic kidney disease, lower extremity artery disease, coronary artery disease
\end{abstract}

\begin{abstract}
Atherosclerosis is the main cause of lower extremity artery disease (LEAD) and coronary artery disease (CAD). These two arterial territories share the major cardiovascular risk factors: smoking, hypertension, dyslipidaemia and diabetes. Current guidelines draw attention to other possible risk factors: homocysteine level, inflammation markers (e.g. high-sensitive $C$ reactive-protein $(C R P)$, interleukin 6) and chronic kidney disease (CKD.) The objective of this study was to evaluate the cardiovascular risk factors strength association with LEAD and CAD on a study population of 203 patients. Our study concluded that smoking seems to be the most powerful risk factor for LEAD, especially for significant lesion in femoral arteries, while diabetes mellitus, hypertension and CKD were significantly associated with CAD. The highest chance of association with multivessel-CAD is for diabetes mellitus compared to hypertension and CKD respectively. Moreover, in diabetic patients the percent of multivessel-CAD was significantly higher than the percent of single-CAD and nonsignificant $C A D$.
\end{abstract}

\section{INTRODUCTION}

Lower extremity artery disease (LEAD) and coronary artery disease (CAD) are associated with considerable morbidity, diminished quality of life and mortality.(1) These two pathologies refer to different degrees of arterial stenosis subsequent to several causes: embolism, thrombosis, vasculitis disease and atherosclerotic disease.(2) Atherosclerosis is the most common cause of LEAD and CAD; thus, this two arterial territories share the major cardiovascular risk factors: smoking, hypertension, dyslipidaemia and diabetes (3). However, current guidelines also draw attention to other possible risk factors for atherosclerotic disease: homocysteine level, markers of inflammation (e.g. high-sensitive $\mathrm{C}$ reactive-protein (CRP), fibrinogen, interleukin 6) (4) and chronic kidney disease (CKD).

Each risk factor is associated with variable strength with each vascular territory; thus, screening of all major risk factors should be considered.(3)

Each vascular region affected by atherosclerotic disease can be considered a marker of cardiovascular risk.(3)

Atherosclerosis is a slow process, which leads to a disease slow progression. In this context, early identification and control of risk factors may contribute to a late symptomatology onset, less severe disease, better outcome and life quality improvement.

\section{AIM}

The aim of the current study is to evaluate the strength of association between cardiovascular risk factors and LEAD versus CAD.

\section{MATERIALS AND METHODS}

From January 2017 to December 2019, 203 patients with symptomatic LEAD were evaluated. The patients underwent digital subtraction angiography for LEAD evaluation and coronary angiography for CAD evaluation in Sibiu County Clinical Emergency Hospital, CVASIC research centre.

Significant LEAD and CAD were defined as at least one lesion with $\geq 50 \%$ lumen diameter stenosis. Lower extremity arteries were divided into three segments: iliac (common iliac artery, external iliac artery, internal iliac artery), femoral (common femoral artery, superficial femoral artery) and infrapopliteal (popliteal artery, tibioperonier trunk, anterior tibial artery, posterior tibial artery, fibular artery). CAD was classified as significant-CAD (any coronary artery stenosis $\geq$ $50 \%$ lumen diameter in left main (LM) artery or left anterior descending (LAD) artery or circumflex artery (CA) or right coronary artery (RCA)) or non-significant-CAD (without coronary artery stenosis $\geq 50 \%$ lumen) and as single-CAD (only one of LAD or CA or RCA with lesion above 50\%) or multivessel-CAD (LM stenosis $\geq 50 \%$, or any of two arteries from LAD, CA, RCA with arterial stenosis $\geq 50 \%$ ).

Hypertension, dyslipidaemia and diabetes were defined according to current guidelines: hypertension as a history of antihypertensive drug use or newly diagnosed hypertension by repeated arterial blood pressure measurements (at least two) $\geq 140 / 90 \mathrm{mmHg}$ during hospitalization, diabetes was considered present when patients were taking an hypoglycemic treatment - oral agents or insulin, and/or had a fasting glucose level $\geq 126 \mathrm{mg} / \mathrm{dL}$ or glycosylated hemoglobin $\geq$ $6.5 \%$. Dyslipidemia diagnosis was considered if a patient had a history of lipid-lowering therapy (statin) use, or had a total cholesterol level $\geq 200 \mathrm{mg} / \mathrm{dL}$ or triglyceride (TG) level $\geq 150$ $\mathrm{mg} / \mathrm{dL}$. The patients were considered positive for smoking if they were active smokers or former smokers - but not more than

${ }^{1}$ Corresponding author: Cornel Ioan Bitea, Str. Corneliu Coposu, Nr. 2-4, Sibiu, România, E-mail: cornelioanbitea@yahoo.com, Phone: +40766 210522

Article received on 17.02.2021 and accepted for publication on 02.03.2021 


\section{CLINICAL ASPECTS}

1 year abstinence.

Normal values for $\mathrm{C}$ reactive-protein in our laboratory were $0-5 \mathrm{mg} / \mathrm{dl}$. Chronic kidney disease was classified form grade I to $\mathrm{V}$ according to KDOQI classification, and creatinine clearance was calculated with Cockcroft-Gault formula.

Statistical analysis was performed using IBM SPSS Statistic software. The Shapiro-Willk test was used to analyse data normality. Normally distributed continuous variables were expressed as the mean $\pm \mathrm{SD}$, and non-normally distributed continuous variables were expressed as the median value. Pearson Chi-Square tests, for discontinuous variables, and Kruskal Wallis test, for continuous variables, were used to evaluate the risk factors association with LEAD and CAD. Statistical significance was considered at a $\mathrm{P}$ value $<0.05$ (twotailed).

\section{RESULTS}

Patients' characteristics

Of the 203 patients with symptomatic LEAD, 166 $(81.8 \%)$ were males, $37(18.2 \%)$ were females; the mean age was $65.31 \pm 8.616$ (range 39-85years). $135(64.5 \%)$ patients were in stage II Leriche-Fontaine, $40(19.7 \%)$ in stage III LericheFontaine, $28(13.8 \%)$ in stage IV Leriche Fontaine. Hypertension had the higher prevalence in our study group $(79.8 \%)$ followed by smoking (76.84\%), CKD (58,1\%), hypercholesterolemia $(54.7 \%)$, hypertriglyceridemia $(48.3 \%)$ and diabetes mellitus $(34.5 \%)$. The majority of patients were with stage II Leriche-Fontaine LEAD with a mean claudication index of $144 \pm 24 \mathrm{~m}$ and a mean ankle-brachial index of $0.62 \pm 0.24$.

Patient's demographic, clinical and biological characteristics are summarised in table no. 1 and table no. 2 .

Table no. 1. Patients' demographic and clinical characteristics

\begin{tabular}{|c|c|c|c|}
\hline Variable & \multicolumn{3}{|c|}{ Value } \\
\hline Age, years & $65.31 \pm 8.6$ & Min: 39 & Max: 85 \\
\hline \multirow[t]{2}{*}{ BMI, $\mathrm{kg} / \mathrm{m}^{2}$} & $27.44 \pm 4.48$ & Min: 17.72 & Max: 43.21 \\
\hline & \multicolumn{2}{|c|}{$\begin{array}{l}\text { Underweight } \\
\text { Normal weight } \\
\text { Overweight } \\
\text { Grade I obesity } \\
\text { Grade II obesity } \\
\text { Grade III obesity }\end{array}$} & $\begin{array}{ll}2 & (1 \%) \\
67 & (33 \%) \\
82 & (40.4 \%) \\
40 & (19.7 \%) \\
10 & (4.9 \%) \\
2 & (1 \%)\end{array}$ \\
\hline Gender & \multicolumn{2}{|l|}{$\begin{array}{l}\text { Male } \\
\text { Female }\end{array}$} & $\begin{array}{l}166(81.8 \%) \\
37(18.2 \%)\end{array}$ \\
\hline Smoking & \multicolumn{2}{|l|}{$\begin{array}{l}\text { Yes } \\
\text { No }\end{array}$} & $\begin{array}{l}156(76.84 \%) \\
47(23.16 \%)\end{array}$ \\
\hline Diabetes mellitus (DM) & \multicolumn{2}{|l|}{$\begin{array}{l}\text { Yes } \\
\text { No }\end{array}$} & $\begin{array}{l}70(34.5 \%) \\
133(65.5 \%)\end{array}$ \\
\hline Hypertension & \multicolumn{2}{|l|}{$\begin{array}{l}\text { Yes } \\
\text { Grade I } \\
\text { Grade II } \\
\text { Grade III } \\
\text { No }\end{array}$} & $\begin{array}{l}162(79.8 \%) \\
0(0 \%) \\
76(37.4 \%) \\
85(41.9 \%) \\
41(20.2 \%)\end{array}$ \\
\hline Hypercholesterolemia & \multicolumn{2}{|l|}{$\begin{array}{l}\text { Yes } \\
\text { No }\end{array}$} & $\begin{array}{l}111(54.7 \%) \\
92(45.3 \%)\end{array}$ \\
\hline Hypertriglyceridemia & \multicolumn{2}{|l|}{$\begin{array}{l}\text { Yes } \\
\text { No }\end{array}$} & $\begin{array}{l}98(48.3 \%) \\
105(51.7 \%)\end{array}$ \\
\hline CKD & \multicolumn{2}{|c|}{$\begin{array}{l}\text { Yes (Creatinine clearance } \\
\left.<90 \mathrm{ml} / \mathrm{min} / 1.73 \mathrm{~m}^{2}\right) \\
\text { Grade II } \\
\text { Grade IIIa } \\
\text { IIIb } \\
\text { Grade IV } \\
\text { Grade V } \\
\text { No }(\text { Creatinine Clearence > } \\
\left.90 \mathrm{ml} / \mathrm{min} / 1.73 \mathrm{~m}^{2}\right)\end{array}$} & $\begin{array}{cc}118 & (58.1 \%) \\
& \\
85 & (41.9 \%) \\
28 & (13.8 \%) \\
3 & (1.5 \%) \\
0 & (0 \%) \\
1 & (1 \%) \\
& \\
85 & (41.9 \%)\end{array}$ \\
\hline $\begin{array}{l}\text { Leriche-Fontaine } \\
\text { classification }\end{array}$ & \multicolumn{2}{|c|}{$\begin{array}{l}\text { I : Asymptomatic } \\
\text { IIa: } \\
\text { claudication at more than } \\
200 \text { m walk } \\
\text { IIb: }\end{array}$} & $\begin{array}{ll}0 & (0 \%) \\
17 & (8.4 \%) \\
118 & (58.1 \%)\end{array}$ \\
\hline
\end{tabular}

\begin{tabular}{|c|c|c|c|}
\hline & $\begin{array}{l}\text { claudicatio } \\
\text { m walk } \\
\text { III: limb re } \\
\text { IV: ische }\end{array}$ & $\begin{array}{l}\text { ess than } 200 \\
\text { in }\end{array}$ & $\begin{array}{l}40(19.7 \%) \\
28(13.8 \%)\end{array}$ \\
\hline $\begin{array}{l}\text { Claudication index, m } \\
\text { Ankle-Brachial index }\end{array}$ & $\begin{array}{l}144 \pm 24 \\
0.62 \pm 0.24\end{array}$ & $\begin{array}{l}\text { Min: } 0 \\
\text { Min: } 0\end{array}$ & $\begin{array}{l}\text { Max: } 1000 \\
\text { Max: } 1\end{array}$ \\
\hline
\end{tabular}

Table no. 2. Patients' biological characteristics
\begin{tabular}{|l|l|l|l|}
\hline Parameter & Mean \pm SD & Minimun & Maximum \\
\hline $\begin{array}{l}\text { Total cholesterol, } \\
\mathrm{mg} / \mathrm{dl}\end{array}$ & $207.60 \pm 55.86$ & 107 & 357 \\
\hline $\begin{array}{l}\text { LDL-cholesterol, } \\
\mathrm{mg} / \mathrm{dl}\end{array}$ & $117.57 \pm 43.76$ & 31 & 290 \\
\hline $\begin{array}{l}\mathrm{HDL}-\text { cholesterol, } \\
\mathrm{mg} / \mathrm{dl}\end{array}$ & $44.91 \pm 10.93$ & 27 & 86 \\
\hline Triglycerides, mg/dl & $185.78 \pm 148.4$ & 44 & 1356 \\
\hline Creatinine, mg/dl & $1.02 \pm 0.59$ & 0.55 & 6.88 \\
\hline $\begin{array}{l}\text { Clearance Creatinine, } \\
\mathrm{ml} / \text { min/1.73m }\end{array}$ & $85.75 \pm 25.59$ & 8.32 & 166.99 \\
\hline $\begin{array}{l}\text { C reactive-protein }, \\
\mathrm{mg} / \mathrm{dl}\end{array}$ & $8.07 \pm 12.79$ & 0.57 & 127.62 \\
\hline
\end{tabular}

\section{Risk factors association with LEAD}

In our study population smoking was highly associated with significant arterial stenosis in iliac and femoral segments (table no. 3). 92 (59\%) smoking patients had significant iliac lesions, versus $19(40 \%)$ non-smokers patients with significant iliac lesions. The association was statistically significant $(\mathrm{p}=0.021)$. In femoral segment a statistically


chance of smoking association is with significant lesions in femoral segment (likelihood ratio 20.85) compared with iliac segment (likelihood ratio 8.3) For infrapopliteal segment the association was not statistically significant (p 0.356).

Table no. 3. Smoking association with LEAD

\begin{tabular}{|l|c|c|c|c|c|c|}
\hline $\begin{array}{l}\text { Arterial } \\
\text { stenosis }>50 \\
\text { \% }\end{array}$ & \multicolumn{2}{|c|}{ Smoking } & \multicolumn{5}{c|}{ Chi Square test } \\
\hline & Yes & No & $\chi^{2}$ & df & p & $\begin{array}{c}\text { Like- } \\
\text { lihood } \\
\text { ratio }\end{array}$ \\
\hline Iliac segment & $92(59 \%)$ & $19(40 \%)$ & 7.7 & 2 & $\mathbf{0 . 0 2 1}$ & $\mathbf{8 . 3 0}$ \\
\hline $\begin{array}{l}\text { Femoral } \\
\text { segment }\end{array}$ & 132 & 47 & 17. & 2 & $\mathbf{0 . 0 0 0}$ & $\mathbf{2 0 . 8 5}$ \\
\hline $\begin{array}{l}\text { Infrapopliteal } \\
\text { segment }\end{array}$ & $134.7 \%)$ & $(100 \%)$ & 4 & & $\mathbf{1}$ & \\
\hline
\end{tabular}

The others risk factors evaluated, diabetes mellitus,

hypertension, $\quad \mathrm{CKD}$, hypercholesterolemia, hypertriglyceridemia, $\mathrm{C}$ reactive protein were not associated with significant arterial stenosis in any of the iliac, femoral and infrapopliteal arterial segments ( $>00.05)$ as shown in table no.4.

Table no. 4. Diabetes mellitus, hypertension, CKD, hypercholesterolemia, hypertriglyceridemia, $\mathrm{C}$ reactive protein association with LEAD.

\begin{tabular}{|l|l|l|l|l|l|l|}
\hline $\begin{array}{l}\text { Arterial } \\
\text { stenosis } \\
\text { \% }\end{array}$ & DM & $\begin{array}{l}\text { Hyper- } \\
\text { tension }\end{array}$ & CKD & $\begin{array}{l}\text { Hyper- } \\
\text { choleste } \\
\text { rolemia }\end{array}$ & $\begin{array}{l}\text { Hyper- } \\
\text { triglycer } \\
\text { idemia }\end{array}$ & CRP \\
\hline & \multicolumn{6}{|c|}{$\mathrm{p}$ two-tailed Chi-Square Test } \\
\hline $\begin{array}{l}\text { Iliac } \\
\text { segment }\end{array}$ & 0.241 & 0.891 & 0.986 & 0.890 & 0.349 & 0.058 \\
\hline $\begin{array}{l}\text { Femoral } \\
\text { segment }\end{array}$ & 0.116 & 0.096 & 0.445 & 0.144 & 0.349 & 0.337 \\
\hline $\begin{array}{l}\text { Infrapoplitea } \\
\text { 1 segment }\end{array}$ & 0.158 & 0.708 & 0.249 & 0.819 & 0.174 & 0.058 \\
\hline
\end{tabular}

Similar with the value of total cholesterol, LDLcholesterol value was not significantly associated with significant LEAD, in none of the three arterial segments: iliac $(\mathrm{p}=0.786)$, femoral $(\mathrm{p}=0.461)$, infrapopliteal $(\mathrm{p}=0.342)$.

$$
\text { Risk factors association with CAD }
$$

$$
\text { In our study population smoking, }
$$

hypercholesterolemia, hypertriglyceridemia was not 


\section{CLINICAL ASPECTS}

significantly associated with significant CAD or multivesselCAD as shown in table no. 5 .

Table no. 5. Smoking, hypercholesterolemia, hypertriglyceridemia association with CAD

\begin{tabular}{|c|c|c|c|c|c|c|}
\hline \multirow[b]{2}{*}{ CAD } & \multicolumn{2}{|c|}{ Smoking } & \multicolumn{4}{|c|}{ Chi Square test } \\
\hline & Yes & No & $\chi^{2}$ & df & $\mathrm{p}$ & $\begin{array}{c}\text { Like- } \\
\text { lihood } \\
\text { ratio }\end{array}$ \\
\hline $\begin{array}{l}\text { Significant } \\
\text { CAD }\end{array}$ & $\begin{array}{c}111(71.2 \\
\%)\end{array}$ & $\begin{array}{c}38(80.9 \% \\
)\end{array}$ & 1.74 & 1 & 0.187 & 1.82 \\
\hline \multirow[t]{3}{*}{$\begin{array}{l}\text { Multivessel } \\
\text { CAD } \\
\end{array}$} & $\begin{array}{c}73(46.8 \\
\%)\end{array}$ & $\begin{array}{c}28(56.9 \% \\
)\end{array}$ & 2.74 & 2 & 0.254 & 2.81 \\
\hline & \multicolumn{2}{|c|}{ Hypercholesterolemia } & \multicolumn{4}{|c|}{ Chi Square test } \\
\hline & Yes & No & $\chi^{2}$ & $\mathrm{df}$ & $\mathrm{p}$ & $\begin{array}{c}\text { Like- } \\
\text { lihood } \\
\text { ratio }\end{array}$ \\
\hline \multirow[t]{3}{*}{$\begin{array}{l}\text { Multivessel } \\
\text { CAD }\end{array}$} & $56(50.5 \%)$ & $\begin{array}{c}45(48.9 \% \\
)\end{array}$ & 0.19 & 2 & 0.908 & 0.193 \\
\hline & \multicolumn{2}{|c|}{ hypertriglyceridemia } & \multicolumn{4}{|c|}{ Chi Square test } \\
\hline & Yes & No & $\chi^{2}$ & $\mathrm{df}$ & $\mathrm{p}$ & $\begin{array}{c}\text { Like- } \\
\text { lihood } \\
\text { ratio }\end{array}$ \\
\hline $\begin{array}{l}\text { Multivessel } \\
\text { CAD }\end{array}$ & $50(51 \%)$ & $\begin{array}{c}51(48.6 \% \\
)\end{array}$ & 2.07 & 2 & 0.354 & 2.09 \\
\hline
\end{tabular}

hypertension and CKD were significantly associated with significant $\mathrm{CAD}$ and multivessel-CAD $(\mathrm{p}<0.05)$. The highest chance of association with multivessel-CAD is for diabetes mellitus (likelihood ratio 28.73), compared to hypertension (likelihood ratio 12.14) and CKD (likelihood ratio 6.23), respectively (table no. 6).

Table no. 6. Diabetes mellitus, hypertension and CKD association with CAD

\begin{tabular}{|c|c|c|c|c|c|c|}
\hline \multirow[b]{2}{*}{ CAD } & \multicolumn{2}{|c|}{ Diabetes mellitus } & \multicolumn{4}{|c|}{ Chi Square test } \\
\hline & Yes & No & $\chi^{2}$ & $\mathrm{df}$ & $\mathrm{p}$ & $\begin{array}{l}\text { Like- } \\
\text { lihood } \\
\text { ratio }\end{array}$ \\
\hline $\begin{array}{l}\text { Significant } \\
\text { CAD }\end{array}$ & $61(87.1 \%)$ & $\begin{array}{c}88(66.2 \% \\
)\end{array}$ & 10.3 & 1 & 0.001 & 11.24 \\
\hline \multirow[t]{3}{*}{$\begin{array}{l}\text { Multivessel } \\
\text { CAD }\end{array}$} & $52(74.3 \%)$ & $\begin{array}{c}49(36.8 \% \\
)\end{array}$ & 27.1 & 2 & 0.0001 & 28.73 \\
\hline & \multicolumn{2}{|c|}{ Hypertension } & \multicolumn{4}{|c|}{ Chi Square test } \\
\hline & Yes & No & $\chi^{2}$ & df & $\mathrm{p}$ & $\begin{array}{l}\text { Like- } \\
\text { lihood } \\
\text { ratio }\end{array}$ \\
\hline $\begin{array}{l}\text { Significant } \\
\text { CAD }\end{array}$ & $\begin{array}{c}126(77.8 \\
\%)\end{array}$ & $\begin{array}{c}23(56.1 \% \\
)\end{array}$ & 7.87 & 1 & 0.005 & 7.32 \\
\hline \multirow[t]{3}{*}{$\begin{array}{l}\text { Multivessel } \\
\text { CAD }\end{array}$} & $90(55.6 \%)$ & $\begin{array}{c}11(26.8 \% \\
)\end{array}$ & 12.08 & 2 & 0.002 & 12.14 \\
\hline & \multicolumn{2}{|c|}{ CKD } & \multicolumn{4}{|c|}{ Chi Square test } \\
\hline & Yes & No & $\chi^{2}$ & $\mathrm{df}$ & $\mathrm{p}$ & $\begin{array}{c}\text { Like- } \\
\text { lihood } \\
\text { ratio }\end{array}$ \\
\hline $\begin{array}{l}\text { Significant } \\
\text { CAD }\end{array}$ & $94(79.7 \%)$ & $\begin{array}{c}55(64.7 \% \\
)\end{array}$ & 5.66 & 1 & 0.017 & 5.60 \\
\hline $\begin{array}{l}\text { Multivessel } \\
\text { CAD }\end{array}$ & $66(55.9 \%)$ & $\begin{array}{c}35(41.2 \% \\
)\end{array}$ & 6.26 & 2 & 0.044 & 6.23 \\
\hline
\end{tabular}

Also, in diabetic patients the percent of multivesselCAD was significantly higher $(74.3 \%)$ than the percent of single-CAD (17.1\%) and non-significant CAD (8.6\%).

\section{DISCUSSIONS}

The predominance of male gender in our study group is concordant with literature data, both LEAD and CAD affecting more frequently males than females. $(5,6)$ The mean age in the studied group correspond to literature information; it is well known that the risk of developing CAD and LEAD increases with age, and includes age greater than 45 years in men and greater than 55 years in women. $(5,6)$

The increased incidence of smoking, hypertension and hypercholesterolemia among studied patients coincides with literature data. $(4,5)$

Smoking was found to be a particularly strong risk factor for lower extremity artery disease. In a paper published in
2012 by Joosten et al it was pointed out that smoking has a population attributable fraction for LEAD of approximately $44 \%$.(9) In our study group smoking was highly associated with significant arterial stenosis in iliac and femoral segments, but the association was not statistically significant for infrapopliteal segments.

Regarding smoking and CAD, there is a strong association with ischemic heart disease.(5) Heavy smokers more than 20 cigarettes per day - have a 2 - to 3 -fold increase in total heart disease. Moreover, continued smoking is a very important risk factor for recurrent myocardial infarction. $(5,10)$ In our study population smoking was not significantly associated with CAD.

In the Framingham Heart Study, even high-normal blood pressure (defined as a systolic blood pressure of 130-139 $\mathrm{mm} \mathrm{Hg}$, diastolic blood pressure of $85-89 \mathrm{~mm} \mathrm{Hg}$, or both) increased the risk of cardiovascular disease 2-fold, as compared with healthy individuals.(7) Studies have also shown that a 20 $\mathrm{mmHg}$ increase of systolic blood pressure was associated with a $63 \%$ higher risk for LEAD.(8) In our study group hypertension was significantly associated with $\mathrm{CAD}$, but there was no significant association with LEAD.

Dyslipidemia is a major cardiovascular risk factor. The risk of CAD increases proportional with the cholesterol level, as shown in Framingham Heart Study.(5,7) Hypercholesterolemia is a significant contributor to peripheral artery disease, being independently associated with incident clinical LEAD.(9) Several studies have shown that high LDLcholesterol and low HDL-cholesterol are associated with an increased risk for atherosclerotic disease.(4) Moreover, in large epidemiological studies, high levels of HDL-cholesterol ware found to be protective for CAD and LEAD. $(4,11)$ In univariate analysis hypertriglyceridemia is associated with LEAD, but in multivariate analysis it usually drops out as an independent risk factor. $(4,12,13)$ In our study group hypercholesterolemia and hypertriglyceridemia were not associated with significant arterial stenosis in any of the iliac, femoral and infrapopliteal arterial segments and with significant CAD. The small number of patients enrolled in this study among with lipid-lowering therapy can explain this discordant result compared to literature data.

Diabetes mellitus is an important risk factor for CAD and LEAD. Diabetic patients are more likely to experience future cardiovascular events compared with healthy population. $(5,14)$ Strong diabetes - LEAD association was proved in populations studies, with ORs ranging from 1.9 to 4. $(4,12)$ For our study group diabetes mellitus was significantly associated with significant $\mathrm{CAD}$ and multivessel-CAD. Moreover, the percent of diabetic patients with multivesselCAD was significantly higher than the percent of diabetic patients with single-CAD and non-significant CAD. On the other hand, diabetes was not associated with LEAD in our study group, probably due to the small cohort and small percent of diabetic patients evaluated.

Classic cardiovascular risk factors are common findings in CKD patients, but CKD brings additional specific risk factors that promote atherosclerotic process (e.g. procalcific state, chronic inflammation and hypoalbuminemia.(16) $\mathrm{CKD}$ is also an independent risk factor for CAD, being associated with both development and severity of CAD.(15) In this study, CKD was significantly associated with significant $\mathrm{CAD}$ and multivessel CAD, but there was no association with LEAD.

A large number of studies have shown that inflammation plays an important role in atherosclerosis pathophysiology (4). High-sensitivity C-reactive protein is an inflammation marker and is associated with an increased risk of 


\section{CLINICAL ASPECTS}

LEAD presence, progression and complication.(17) In our study group, the C-reactive protein was determined and not the Highsensitivity C-reactive protein and no significant association with LEAD was detected.

The main limitation of this study is the small numbers of patients enrolled. This is a possible explanation for discordant study result with literature data.

\section{CONCLUSIONS}

LEAD and CAD share the same cardiovascular risk factors. The strength of associations between each conventional or non-conventional cardiovascular risk factor with LEAD and CAD was an important topic in large epidemiological studies.

Among risk factors evaluated in this study, smoking and hypertension had the higher prevalence followed by CKD and hypercholesterolemia.

In our study group, only smoking was strongly associated with LEAD. The other risks factors - diabetes mellitus, hypertension, dyslipidaemia, CKD and C-reactive protein - did not have statistically significant association with LEAD, probably due to the small number of patients evaluated.

In contrast, for $\mathrm{CAD}$, diabetes mellitus, hypertension, dyslipidaemia and CKD were associated with the presence and severity of coronary lesions; instead smoking was not significantly associated with coronary stenosis $\geq 50 \%$ of lumen diameter.

\section{REFERENCES}

1. Hiramoto JS, Teraa M, de Borst GJ, Conte MS. Interventions for lower extremity peripheral artery disease Nature Reviews Cardiology. 2018;15:332-350.

2. Zipes D, Libby P. Braunwald's Heart Disease: A Textbook of Cardiovascular Medicine, 11th edition; 2018.

3. Aboyans V, Ricco JB, Bartelink MEL, et al. 2017 ESC Guidelines on the Diagnosis and Treatment of Peripheral Arterial Diseases, in collaboration with the European Society for Vascular Surgery (ESVS). European Heart Journal. 2018;39:763-821.

4. Aboyans V, Ricco JB, Bartelink MeL, et al. 2017 ESC Guidelines on the Diagnosis and Treatment of Peripheral Arterial Diseases, in collaboration with the European Society for Vascular Surgery (ESVS) - Web Addenda. European Heart Journal.2017; 00:1-22. doi:10.1093/eurheartj/ehx095.

5. Boudi FB, Yasmine S. Risk Factors for Coronary Artery Disease: https://emedicine.medscape.com/article/164163overview\#a3 Mar 30, 2020.

6. Fowker FG, RudanD, Rudan I, et al. Comparison of global estimates of prevalence and risk factors for peripheral artery disease in 2000 and 2010: a systemic review and analysis. Lancet. 2013;382:1329-1340.

7. Vasan RS, Larson MG, Leip EP et al. Impact of highnormal blood pressure on the risk of cardiovascular disease. N Engl J Med. 2001;345(18):1291-7.

8. Emdin CA, Anderson SG, Callender T et al. Usual blood pressure, peripheral arterial disease, and vascular risk: cohort study of 4.2 million adults. BMJ 2015; 351:h4865.

9. Joosten MM, Pai JK, Bertoia ML, Rimm EB et al. Associations between conventional cardiovascular risk factors and risk of peripheral artery disease in men. JAMA. 2012;308:1660-1667.

10. Rea TD, Heckbert Sr, Kaplan RC et al. Smoking status and riskfor recurrent coronary events after myocardial infaction. Ann Intern Med. Sep 17 2002;137(6):494-500.

11. Ridker PM, Stampfer MJ, Rifai N. Novel risk factors for systemic atherosclerosis: a comparison of C-reactive protein, fibrinogen, homocysteine, lipoprotein(a), and standard cholesterol screening as predictors of peripheral arterial disease. JAMA. 2001;285:2481-2485.

12. Criqui MH, Aboyans V. Epidemiology of peripheral artery disease. Circ Res. 2015;116:1509-152.

13. Murabito JM, Evans JC, Nieto K, Larson MG, Levy D, Wilson PW. Prevalence and clinical correlates of peripheral arterial disease in the Framingham Offspring Study. Am Heart J. 2002;143:961-965.

14. Howard BV, Rodriguez BL, Bennett PH et al. Prevention Conference VI: Diabetes and Cardiovascular Disease: Writing Group I: epidemiology. Circulation. 2002; 105(18):e132-7

15. Sarnak MJ, Levey AS, Schoolwerth AC, et al. Kidney disease as a risk factor for development of cardiovascular disease: a statement from the American Heart Association Councils on Kidney in Cardiovascular Disease, High Blood Pressure Research, Clinical Cardiology, and Epidemiology and Prevention. Circulation. 2003;108(17):2154.

16. Garimella PS, Hirsch AT, Peripheral Artery Disease and Chronic Kidney Disease: Clinical Synergy to Improve Outcomes. Adv Chronic Kidney Dis. 2014 Nov; 21(6):460-471. doi: 10.1053/j.ackd.2014.07.005.

17. Chuang YW, Yu MC, Lin CL, Yu TM, Shu KH, Huang ST, Kao CH. Risk of peripheral arterial occlusive disease in patients with rheumatoid arthritis. A nationwide population-based cohort study. Thromb Haemost 2016;115:439-445. 